\title{
Transnational Financial Companies: Oligopolistic Structure and Property. Some Reflexions
}

\author{
Jose Reyes-Duran \\ National Graduate School Unit Leon, National Autonomous University of Mexico, Mexico
}

Copyright (C) 2015 by authors, all rights reserved. Authors agree that this article remains permanently open access under the terms of the Creative Commons Attribution License 4.0 International License

\begin{abstract}
The economic reproduction process based capital finance consolidates the role of transnational financial companies (TFC) and deepens the crisis of productive accumulation process. In this context, the subsidiaries in emerging countries are responsible for the financial situation of the parent, and the other way around. The proposals for resolving the crisis have not had a comprehensive approach except for stabilizing the financial system, and appear to be the international political will for economic deployment, with incalculable social costs.
\end{abstract}

Keywords Transnational Financial Companies, Oligopolistic Structure, Corporate Ownership

\section{Theoretical Framework}

In recent decades, the $\mathrm{TFC}$ has been strengthened by a set of strategies adopted to maintain profits: they relied on the relocation of economic spaces that were beyond their borders to exploit labor, and indigenous markets; in another sense they arrived with greater force in the given the volatility of interest rates and exchange rates that were offered financial gains promoted by liberalization and financial deregulation financial markets; finally falling barriers to foreign direct investment with hints of speculative (short-term) made affordable strong acquisition and/or merger of the ETF with national companies who saw their future actions hazardous to the imminent arrival of foreign capital.

The high projected profit margins earned by these corporations (TFC) is consequence of the credit crunch, the concentration of banking and insurance system and, contagion among nations are elements that are not foreign to the TFC and configure the operation of the financial system.

Specifically, bank concentration increases barriers to financing companies, especially when the credit market structure is a large share of foreign-owned banks [1]; is also observed that the internal and external exposure of US banks in emerging countries was more sensitive to economic conditions (growth rates and interest) in the USA, which markets countries. [2]

Another line of research has found that when ownership of the banking system of a host country is highly concentrated by external capital, the country can easily spread in the host economy. Thus it is likely that the financial problems in Japan during the eighties and nineties were transmitted through Japanese banks in mortgage markets in the United States. [3] y [4] Strong links through economies have increased the speed at which events can affect a market quickly to others. The risk of contagion takes place wherever and transmission mechanisms of the policies adopted by the shareholders, in response to shocks to their economies of origin or elsewhere who have made investments, are significant [5]

The strategies adopted by foreign parent banks may have serious implications for the functioning of credit markets of the host countries, as is the case in Bolivia where the Spanish banks curtailed lending and other subsidiaries immediately followed that of other banks policy: between 1999 and 2002 credits of these banks decreased by $62 \%$; while recourse to domestic banks, it did so in only $9 \%$.

In the nineties the participation of foreign banks in the financial systems of the host countries accelerated. As shown in the chart below, Spain has gained important positions in banking markets, especially in Latin America.

The question then reasons why foreign banks migrate to other countries? From the perspective of the owners of banks and financial institutions, the most significant thing to note is that the subsidiaries of foreign banks have enjoyed higher margins in interest rates and profits, than those achieved by local banks. [6] and his arrival in emerging countries is the result of competition in developed countries, while its revenue in emerging due to the crisis. [5] Another argument is that the subsidiaries have come to rescue matrices, [7] y [8] contradicts the assumption that the latter supports the former, and the crisis governments have served as lenders of last resort against the commitments to depositors. 
Table 1. Participation of the state, private and foreign banks in the banking systems 2005

\begin{tabular}{|c|c|c|c|c|c|c|c|}
\hline \multirow{2}{*}{ region / country } & \multirow{2}{*}{$\begin{array}{l}\text { State } \\
\text { banks }\end{array}$} & \multirow{2}{*}{$\begin{array}{l}\text { Private } \\
\text { Banks }\end{array}$} & \multicolumn{4}{|c|}{ Foreign banks } & \multirow{2}{*}{$\begin{array}{c}\text { Foreign } \\
\text { Country } \\
\text { more importan }\end{array}$} \\
\hline & & & total & European Union & USA & Others & \\
\hline \multicolumn{8}{|l|}{ Latin America } \\
\hline Argentina & 32.5 & 19.1 & 48.4 & 33.6 & 12.1 & 2.7 & Spain (17.9) \\
\hline Brazil & 46.0 & 27.0 & 27.0 & 15.7 & 5.3 & 6.1 & Spain (5.3) \\
\hline Bolivia & 18.2 & 56.5 & 25.3 & 10.4 & 4.5 & 10.4 & Spain (10.4) \\
\hline Chile & 12.9 & 45.5 & 41.6 & 32.4 & 5.5 & 3.8 & Spain (30.6) \\
\hline Peru & 10.8 & 43.2 & 46.0 & 34.8 & 5.6 & 5.6 & Spain (17.1) \\
\hline Mexico & - & 17.7 & 82.3 & 53.7 & 23.7 & 4.8 & Spain (41.5) \\
\hline \multicolumn{8}{|l|}{ Eastern Europe } \\
\hline Romania & 41.8 & 3.0 & 54.9 & 46.0 & 4.5 & 4.4 & Austria (21.7) \\
\hline Poland & 23.1 & 5.4 & 71.5 & 60.2 & 10.4 & 0.9 & Italy (16.6) \\
\hline Slovakia & 33.0 & 6.4 & 60.5 & 51.8 & 2.8 & 5.9 & $\begin{array}{l}\text { Luxembourg } \\
\quad(34.9)\end{array}$ \\
\hline Bulgaria & 18.1 & 10.3 & 72.0 & 62.9 & 1.3 & 7.8 & Italy (27.0) \\
\hline Czech Republic & 4.3 & 25.7 & 70.0 & 58.1 & 6.3 & 5.6 & Austria (40.5) \\
\hline Estonia & - & 2.0 & 98.0 & 98.0 & - & - & $\begin{array}{c}\text { Switzerland, } \\
(86.3)\end{array}$ \\
\hline Hungary & 44.6 & 3.2 & 52.2 & 39.2 & 8.6 & 4.4 & Austria (17.8) \\
\hline Slovenia & 14.3 & 19.6 & 66.2 & 66.2 & - & - & Belgium (44.5) \\
\hline
\end{tabular}

Source: Almanac of Banks

\section{Measures Governmental: Deregulation, Liberalization and Openness}

Financial and trade policies applied by different countries has been instrumental in the domain of TFC. After three decades of implementation of the Washington Consensus in Mexico has deepened deregulation, and liberalization of financial markets. This benefits the TFC at least through four measures: financial liberalization (especially interest rates) provides a major concessions to banks, non-bank financial institutions and speculators; competitive exchange rate slows fans imports and exports, arbitration and lack of control in defining differential countries that encourage financial gains, with a consequent drop in country risk rating; privatization of public enterprises and, deregulation of markets which eliminated any control over operations and financial maneuvers.

The deregulation policy postulated that the bank would be a segment in which the creation of new entities and authorization for the entry of foreign banks generate an environment of competition that would stimulate efficiency. [9]

In the crisis, and its later stage, has been shown that the subsidiaries have come to rescue parents [7] and [8], so the assumption that the bank headquarters responsible for their banks in other economies is false, given that governments must take responsibility for the depositors and bank bailouts, a few years after privatized banks and liberalized markets, under the assumption that the market solve the crisis.

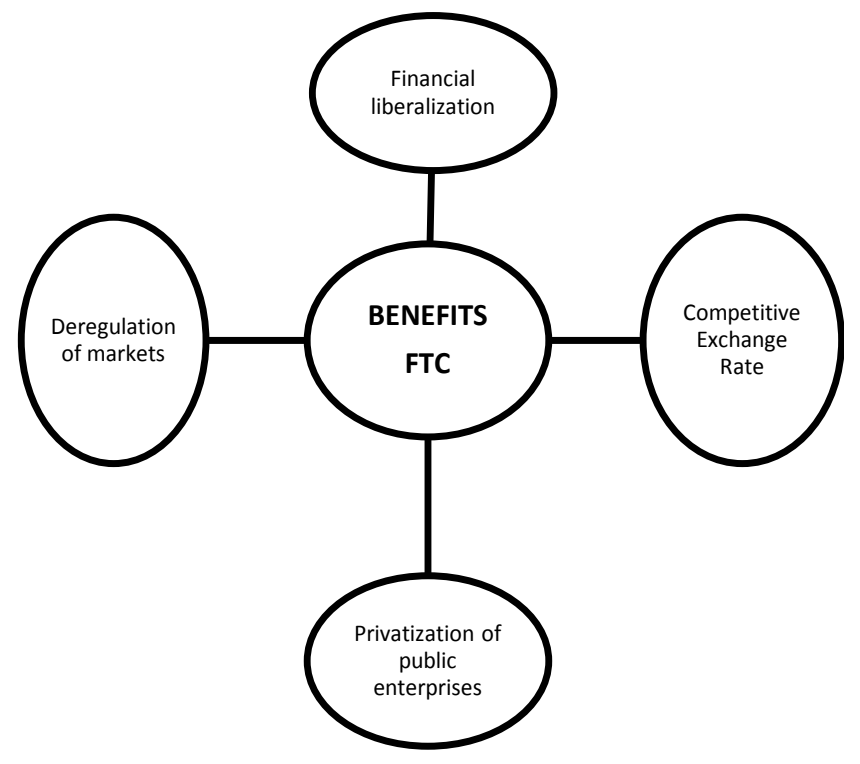

Source: Developing own.

Figure 1. Washington Consensus

In this vein, a key element of the deployment of TFC is the absence of deep comprehensive rules that verify and monitor the functioning of the financial system, a position that is not accepted by any international body. Of the 27 countries that make up the Basel Committee III (Bank for International Settlements) until 2014, just 10 had completed the required capital requirements. The other 17 countries did not seem to be promoting the strengthening of its banks. Among these include the United States and Britain, which have most of the world banking monopolies and whose financial system has 
become a powerful financial complex. [7]

Produce was inconvenient as he could speculate on exchange rates and interest on sovereign debt. The financial system needed a complete freedom to move unregulated long term and across the planet, and the brand new multinational companies were expanding branches [...] hated to see the hand of the state controlling working conditions, profitability and monopolistic concentrations. And Friederick Hayek was rescued from his long relief. [10]

The process of concentration and economic openness to foreign capital and, in particular financial institutions as a launching pad was the neoliberal model

The neoliberal label stated its adherence to free market principles coined by neoclassical economics, which had emerged in the second half of the nineteenth century (thanks to the work of Alfred Marshall, William Stanley Jevons and Leon Walras) to move to the classical theories of Adam Smith, David Ricardo and, of course, Karl Marx. However, it also held to the conclusion that Adam Smith's invisible hand of the market was the best mechanism to mobilize even the deepest instincts of human beings (...) the neoliberal doctrine is deeply opposed to theories that defended the state intervention such as John Maynard Keynes, who won prominence in the 1930s in response to the Great Depression. [11]

In the Mexican space, the process of creating and mastering the ETF leads to the consolidation of processes of concentration and transnationalization, and the current banking regulation is the result of neoliberal spirit and government weakness before the power of the huge international banks [12]

Table 2. Gross fixed capital formation (Growth rates) 2013- 2014

\begin{tabular}{cccccc}
\hline & 2013 & 2014 & 2014 & 2014 & 2014 \\
& Q4 & Q1 & Q2 & Q3 & Q4 \\
\hline Europe & 0.7 & 0.3 & -0.7 & -0.3 & \\
Europe (18 & 0.7 & 0.3 & -0.7 & -0.3 & \\
Countries) & & 3.0 & -1.7 & -1.2 & 1.2 \\
Germany & 1.2 & -0.7 & -0.8 & -0.6 & -0.5 \\
France & 0.1 & -0.7 & 1.3 & 0.5 & -0.5 \\
United & 2.3 & 2.4 & & & \\
Kingdom & & & & \\
EU.A. & 1.1 & -0.7 & 2.3 & 1.6 & 0.6 \\
\hline
\end{tabular}

Source: Eurostat
Table 3. Real GDP growth rate $2010-2014$

\begin{tabular}{cccccc}
\hline & 2010 & 2011 & 2012 & 2013 & 2014 \\
\hline Europe & 2.1 & 1.7 & -0.4 & 0.0 & \\
Europe (18 & 2.0 & 1.6 & -0.7 & -0.5 & \\
Countries ) & & & & & \\
Germany & 4.1 & 3.6 & 0.4 & 0.1 & 1.6 \\
France & 2.0 & 2.1 & 0.3 & 0.3 & 0.4 \\
United Kingdom & 1.9 & 1.6 & 0.7 & 1.7 & 2.6 \\
E.U.A. & 2.5 & 1.6 & 2.3 & 2.2 & 2.4 \\
\hline
\end{tabular}

Source: Eurostat

The costs of implementing the economic reforms (between other factors like reduction investment public and private, in a international context) are observed in the behavior of GDP (Table 2) and gross fixed capital investment (Table 3), as can be seen in the following table showing both variables in some regions and selected countries.

What I wish to emphasize is that the current structure and ownership of the financial market and the measures taken led to the strengthening of TFC operating in our country.

The financial reforms undertaken, especially following the signing of NAFTA and the end of the second half of the nineties, were crucial to reposition the property of external financial capital. Within just a few years, the property of commercial banks and insurance companies [13] (the latter being one that integrates one of the key sectors of the financial system), passed to external private ownership so that the important mechanism of flow of financial resources to productive enterprises was cut off and linked to the flow of money markets and international capital with a final destination in the financial parents.

In forming this domain oligopolistic structure of TFC, has enormous relevance NAFTA and financial reforms that adjusted the specific laws and regulations governing the operation of the financial system in the country. In CHAPTER XIV NAFTA relationship is established financial services through subsidiaries of banks in the three countries. $^{1}$

In 1995, the federal government promoted a disorderly bank reform aimed at increasing the share of foreign capital into the financial system through greater participation in the equity of banks and other local financial agents. Initially three key institutions were excluded (Banamex, Bancomer and Serfin). ${ }^{2}$

1 Specifically, the Annex VII of this treaty establishes a transition period (1994-1999), during which the maximum capital to be authorized by Mexico to a foreign financial subsidiary, calculated as a percentage of the aggregate capital of all financial institutions same type in Mexico, should not exceed $1.5 \%$ in commercial banks and that once the transition period any foreign bank may acquire more than $4 \%$ of the sum of shareholders' equity of all commercial banks completed. [17]

2 Proof of this are the commitments that were agreed limits about NAFTA (which went largely exceeded) and lock in laws to limit foreign ownership of the three largest banks in the country, which in 1998 had to be removed. In 1992, stipulates that foreigners cannot acquire more than $1.5 \%$ of an individual bank, or $8 \%$ of the entire system. In 1995, the individual limit changes from $1.5 \%$ to $6 \%$ and $25 \%$ passes added. Thus, could not be alienated Bancomer, Banamex and Serfín, but in 1998 were eliminated or two limits. [9] 

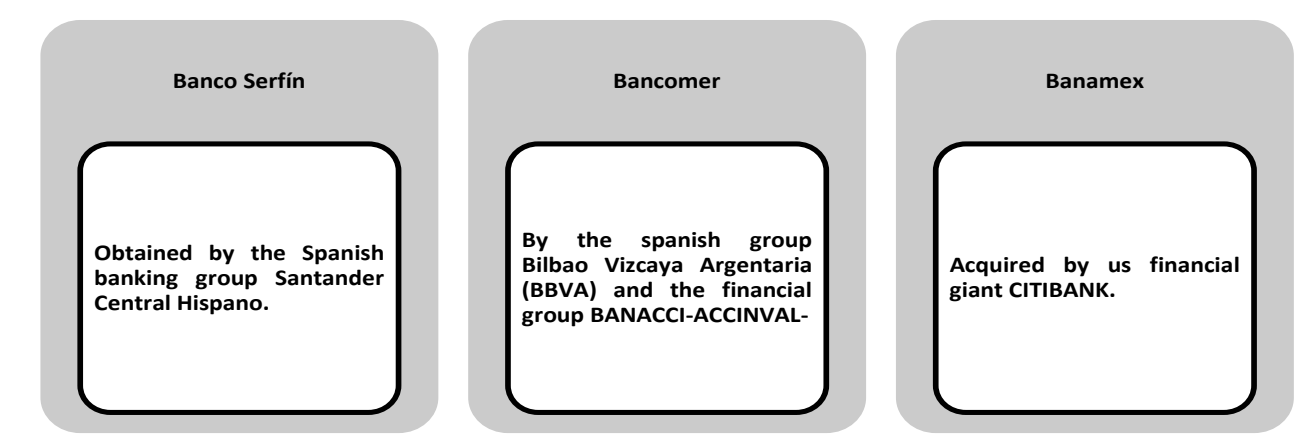

Source: Developing own

Figure 2. Credit institutions act Mexican Procurement

Subsequently, this indication would be solved so that foreign capital would not see any limitation. This situation occurred in 1998 with amendments of banking legislation that expands the rights of bankers to take ownership on bank capital by up to $100 \%$, implying its reorganization before sale - non performing loans (NPLs) was replaced with notes Fobaproa, amply capitalized and profitable, whose interest rate ensured a flat performance for its holders - by the public budget. Thus, the process of denationalization of banks in those years stood in his possession an impressive $80 \%$ of the consolidated assets of the system.

Therefore, with the entry into force of amendments to the Law on Credit Institutions, legal and legal barriers that prevented the participation of foreign capital in full ownership of local banks were eliminated, and in less than three years the presence of foreign capital dominated the commercial banking system and consolidated oligopoly and oligopsonic powers off the bench to set high lending rates in the credit market and low borrowing rates in the deposit market, respectively. [17]

Based on this reform, in just two years (2000-2001), foreign financial conglomerates acquired, as noted above, the three largest banks in the financial system, despite the creation of new small banks. ${ }^{3}$

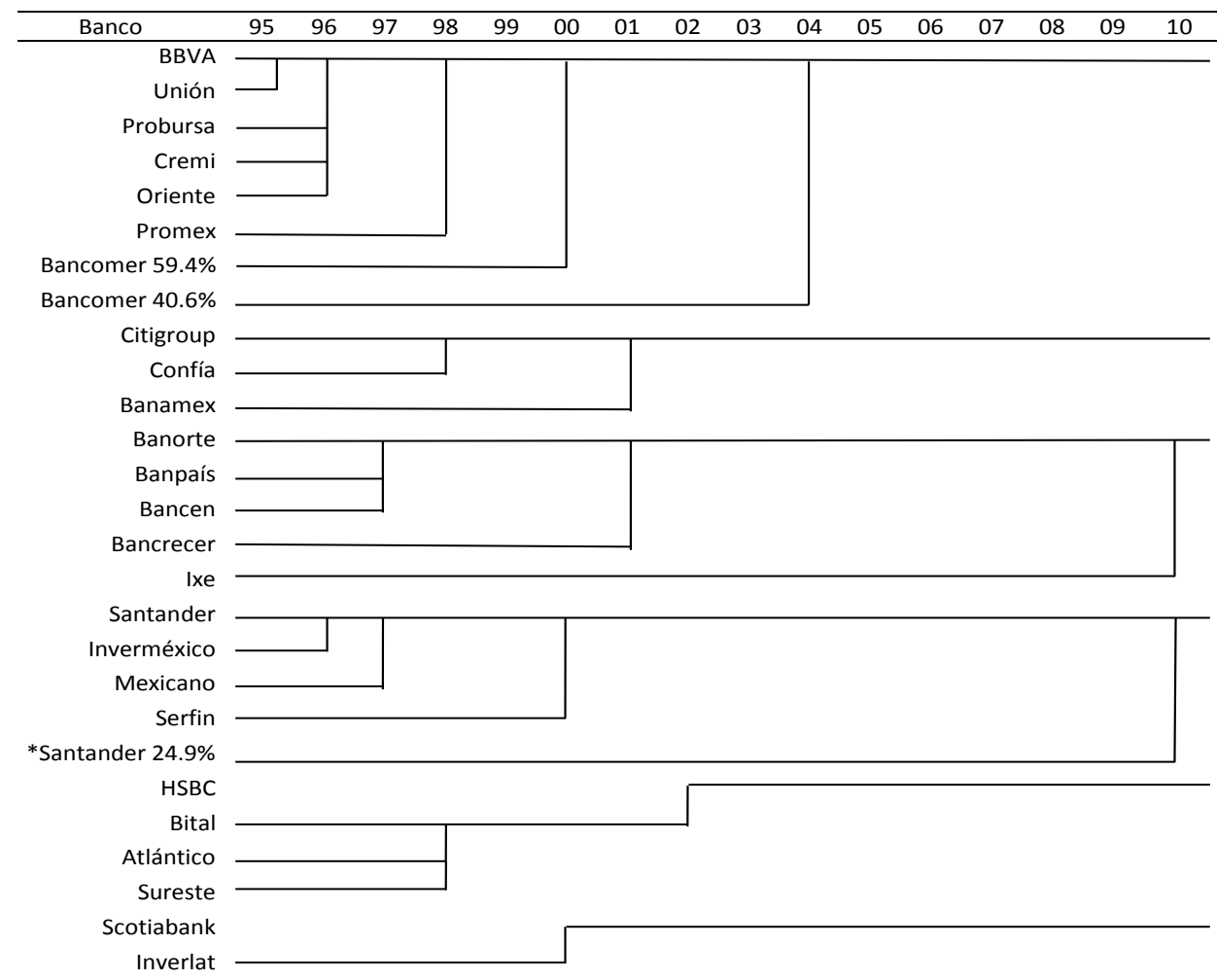

Bank of America acquired 24.9\% of the subsidiary of Santander in Mexico in 2002. In 2010 Santander bought that part to bank of America. Source: Gonzalez, Javier y Pablo Pena(2012), “The Foreign banks in Mexica: There are reasons to worry?” Economic Studies, CNBV, Vol. 1 p.148

Figure 3. Recent history of mergers and acquisitions of the largest banks in Mexico

3 In this wave of new banks are: Banco Regional (Banregio), Commercial Bank of Northeast (Banco Amigo), Autofin, Banco Compartamos Banco Easy, Banco Multiva, Banco de Coppel, Bank Volswagen, Banco Deuno, International Consulting, Bank Wal-Mart, Prudential, and the authorization of subsidiaries of banks USB (Swiss capital) Bank of New York Mellon (US capital), Barclays (English capital). Given its low capitalization, the year of its creation some small banks had to merge or be sold to other banks. [17] 
Years later, in order to increase competition in the banking system, the requirements were eased to authorize the operation of new bank and non-bank financial intermediaries; the response was immediate: in 2006 a boom authorizations for new banks, some belonging to financial groups and others under the tutelage of large commercial or industrial enterprises was recorded; “ [...] From 2008 authorizing the Bank of Mexico finance to banks that have this problem. In this context between 2006-2008 15 banks were authorized, in addition to operations for the purchase of subsidiaries that gave rise to Banco Ve Por Mas and Banco Ahorro Famsa. [17]

[...] The large financial groups, which control a large share of the banking markets are strengthened, consolidating its oligopolistic position in the credit market and therefore their power to set high lending rates. These same financial groups, using their economic capacity and orchestrated strategic oligopolistic position where competition is limited to the diversification and differentiation of financial products and services, as well as greater geographical coverage (network of branches and automated teller machine - ATMs), forming a oligopsony in the deposit market, which means having enough to set borrowing rates low, even below the rates of government bonds power. [17]

As we can see, the difficulty and urgency to capitalize on banks due to the crisis of 1994 - 1995, led to the immediate decision-making that defined the current foreign oligopolistic structure of the industry.

The banking model currently operating nationwide is far from that of the financial liberalization perpetrators whom were raised in Mexico, where a moderate opening of the sector, competition and innovation loomed, increasing service quality and efficiency in operation. They probably never imagined that foreign penetration were to be of the magnitude that is present today.

\section{Oligopolistic Structure and Transnational Ownership}

Deregulation and liberalization of the financial sphere (inter alia) led to the creation of specific standards for the protection of private property, which implies privileging the individual assets over any common good or social need. This warranty gives you sustenance and action to TFC in host countries.

The economic policy on ownership of banks had two stages: the first for privatization of the state bank, the second for foreign ownership of local private banks. The second, sale of companies to control and transnational corporate ${ }^{4}$ domain beyond just selling companies to cleave the resources that make it feasible to solve the fiscal deficit and balance: it implies a change in the economic role - social state, and upsets the sovereignty when foreign capital involved in procurement and target markets where it is positioned. This process has already warned clearly in the early seventies.

From seventies was observed the transition of the ownership process:

We are facing a frontal conflict between transnational corporations and states. These appear interfered in their fundamental economic and military decisions policies for global organizations that are independent of any State in the sum of its activities are not or are controlled by any parliament, by any representative institution of collective interest. In a word, it is the entire political structure of the world that is being undermined. "Salvador Allende [10]

The following diagram shows some traits between foreign direct investment (FDI) and privatization.

4 Banks and insurers influence, initially, government hands to private national, before moving on to the control of foreign, particularly American property. The acquisition mechanism was that future buyers purchased bonds of the country's debt to half its value or less, and traded at par value for purchase. Another method was that the parent company of the purchasing function as lender, thereby returning the borrowed capital was transformed into a huge debt to the former state enterprise, and this then justify layoffs and rate increases. 


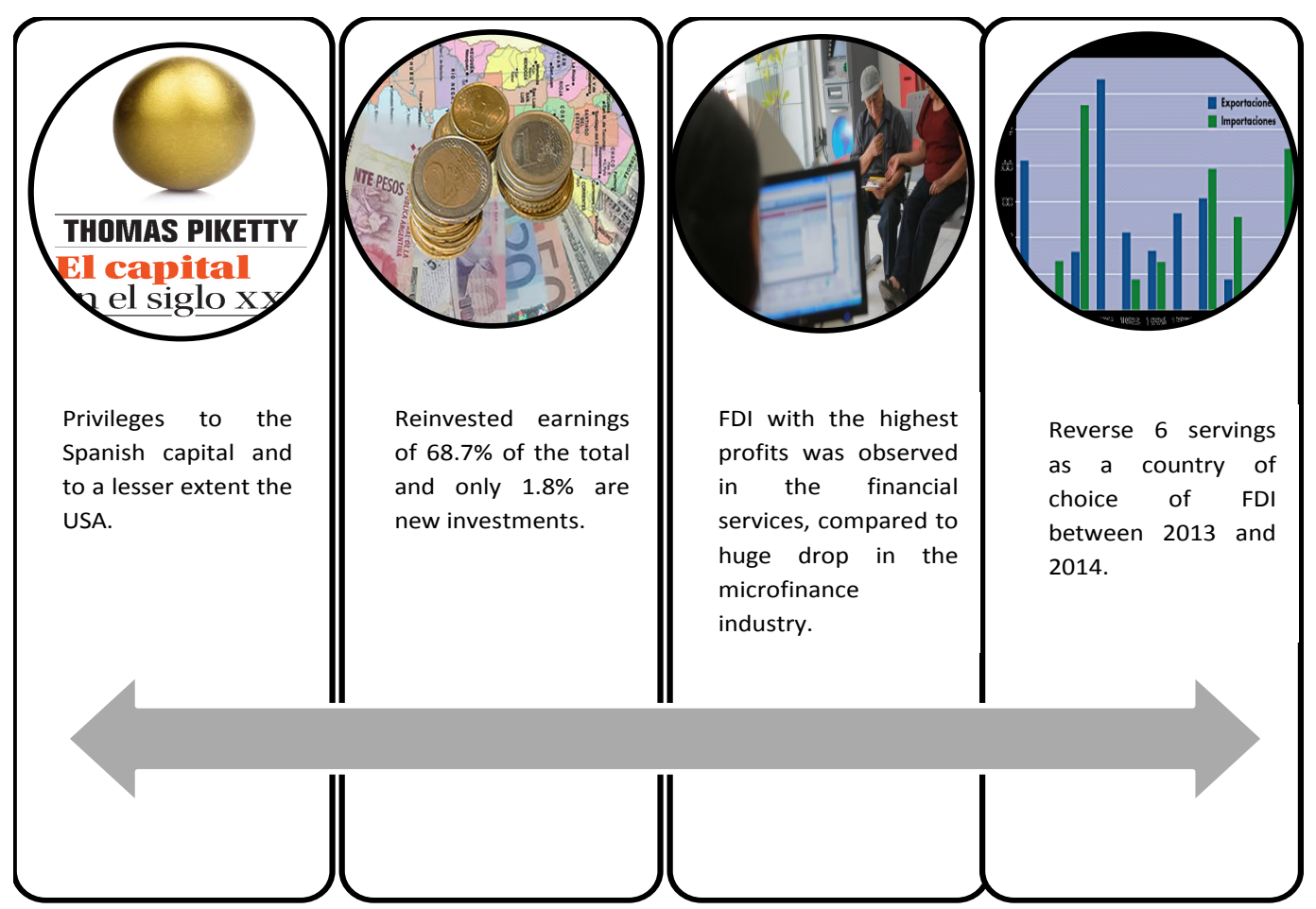

Source: Developing Own

Figure 4. Foreign Direct Investment (FDI) and privatization of enterprise.

In a few years, the property of banking and insurance passed to external private hands so that the important mechanism of the flow of financial resources to productive enterprises was cut and link to the streams of money markets and international capital with final destination financial matrices. [13]

Henceforth, the new financial model was structured as what is known as sui generis:
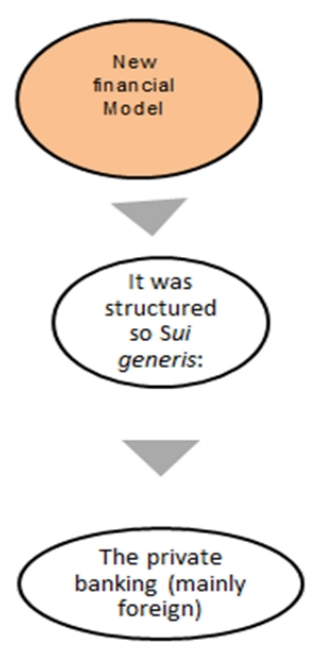

Source: Developing Own.
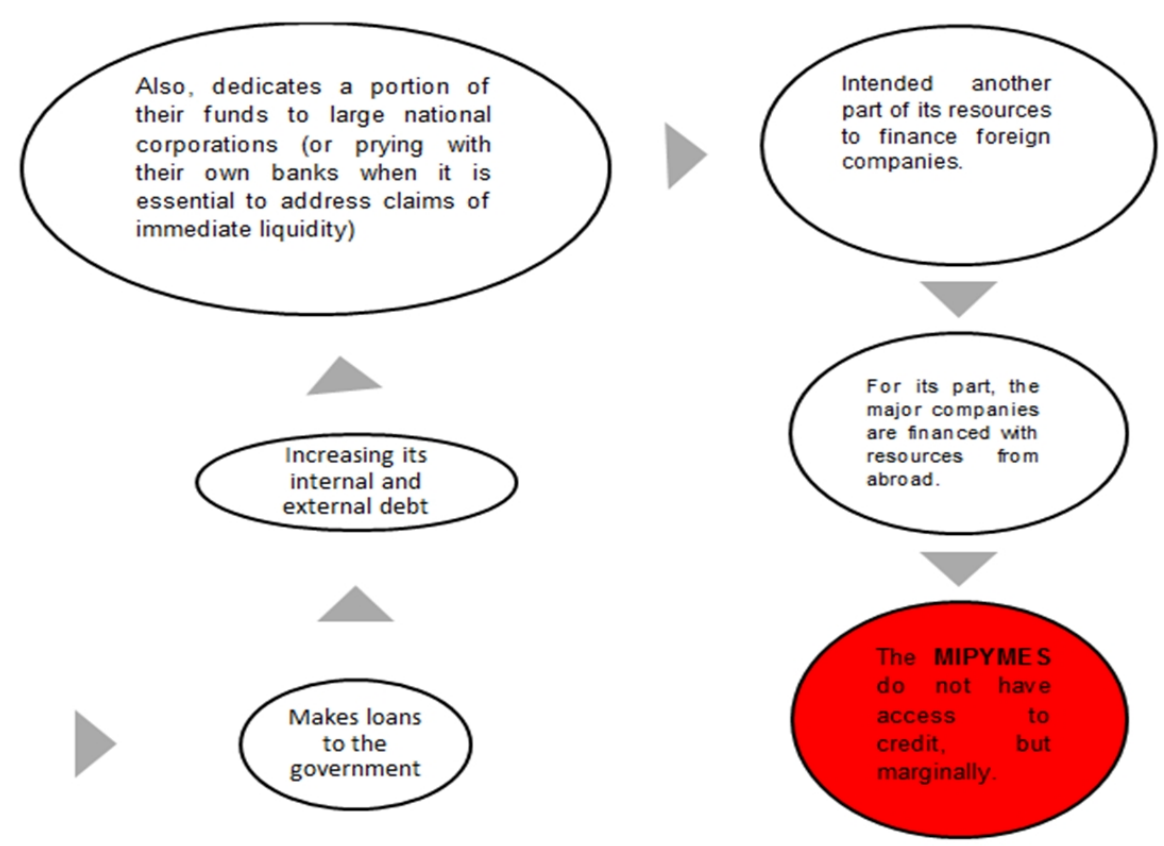

Figure 5. Functioning financial system in Mexico 
In this configuration, the bank achieved high profits and profitability margins, not so much by way of long-term credit, but high fees and outstanding degree of speculation based on their connection to international financial markets by holding operations government bonds and dynamic hedging operations.

As a counterpart of this process, local financial conglomerates lost control of the domestic private financial system at foreign banks. [14]

In recent decades, the TFC has been strengthened by a set of strategies adopted to maintain profits: they relied on the relocation of economic spaces that were beyond their borders to exploit labor, and indigenous markets; in another sense they arrived with greater force in the given the volatility of interest rates and exchange rates that were offered financial gains promoted by liberalization and financial deregulation financial markets; finally falling barriers to foreign direct investment with hints of speculative (short-term) made affordable strong acquisition or merger of the TFC with national companies who saw their future actions hazardous to the imminent arrival of foreign capital.
The UNCTAD's World Investment Prospects Survey 2014-2016, 2014 amounted to Mexico in 13th place in the 17 most attractive investment countries in the world, while a year ago our country was located on the seventh position implying a fall of six places.

Large companies in the world called often multinational, ie that produce and / or distribute products and / or services beyond the country's borders have been repeatedly identified as guides globalization. [15]:7; however, very few of them are global companies. For example, most of the 500 largest companies are based in the regional space whose three main areas are given by North America, the European Union and Asia. So it is firms that are internationally active on the market in their own region, but not in all regions. " [15]:7

In the article entitled "The Network of Global Corporate Control" Vitali et al. [16] identified that only 147 corporations control $47 \%$ of the global economy, almost $50 \%$. Among thousands of companies in more than 150 countries, only 147 are owning half of global GDP. It's crazy!

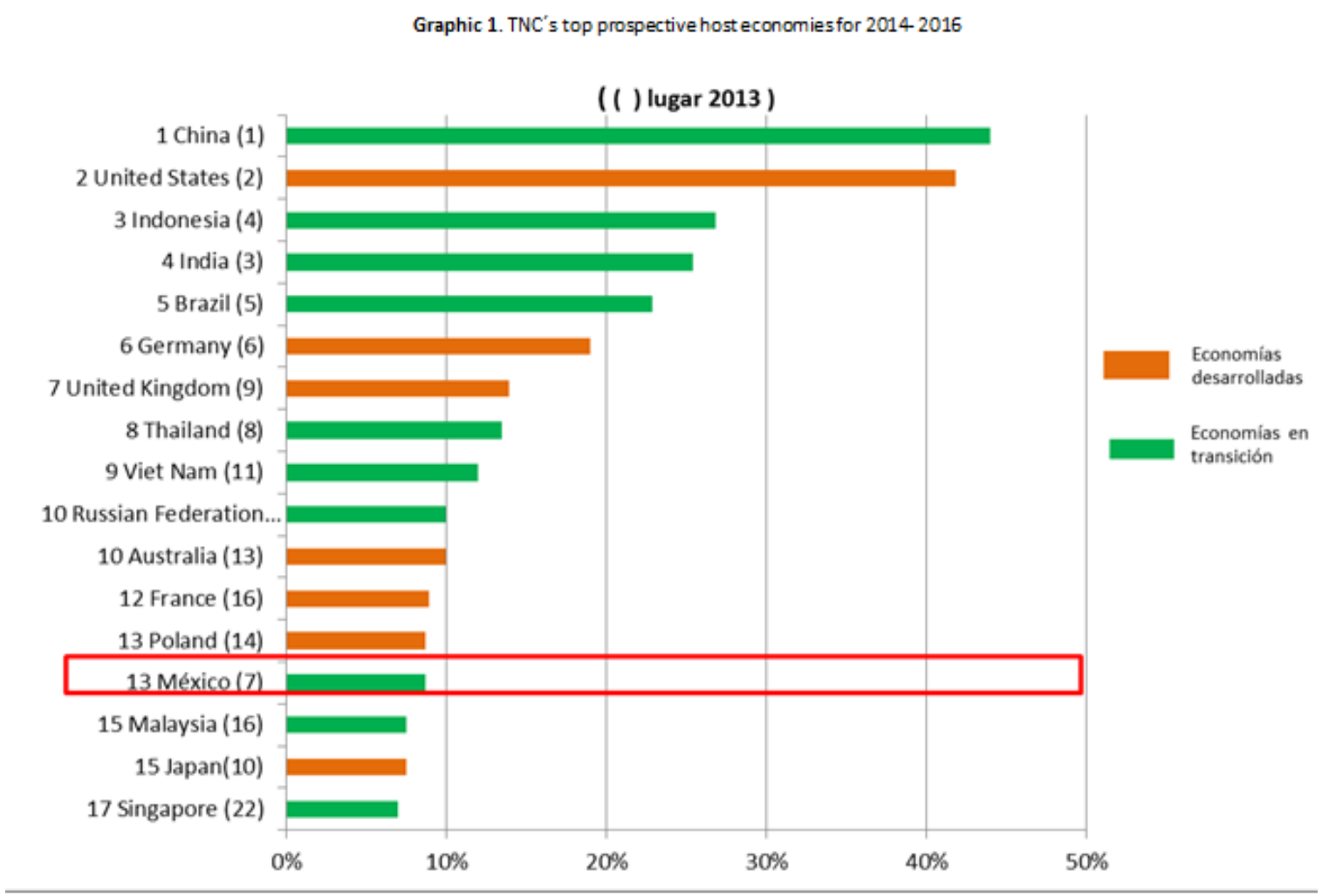

Source: Developing own based on UNCTAD survey.

Note: Based on the responses of 164 companies. 


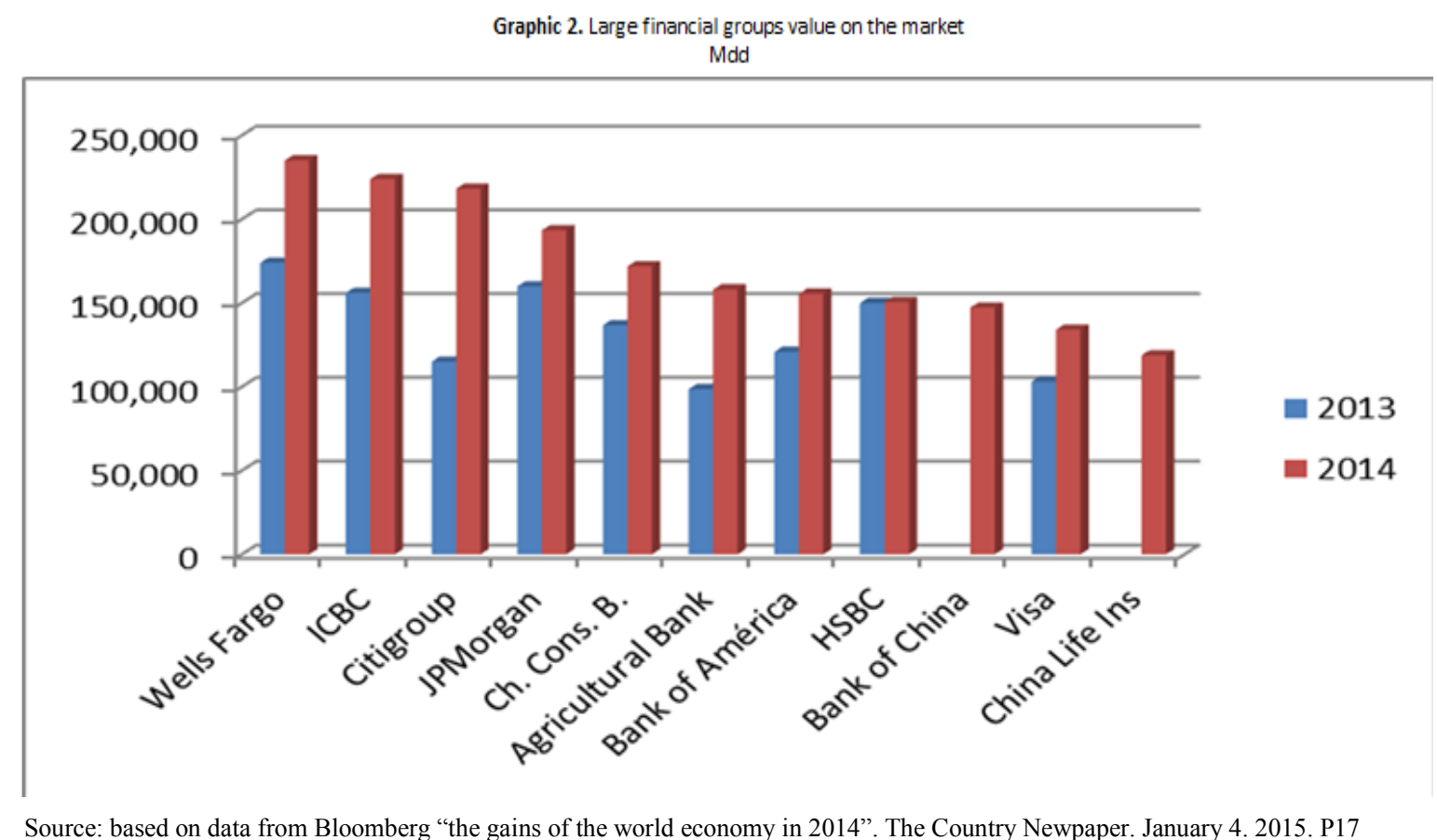

The study also analyzes the stock and corporate ownership of 43.060 transnational corporations, i.e., it is not all firms but just over 43,000 ET. The network of relationships between them led a small group of 1,318 who controlled all the others, but a select group of 147 which determines the performance of the 1,318 that establish control loops of $43.060,0.3 \%$ these.

Hilferding was right on target: owning a small business can gain control of many others to form the powerful financial capital and corporate ownership groups.

Among this small group are the dominant financial corporations like Goldman Sacks and Black Rock, as well as more of the oil, gas, mining, etc. This process of concentration is based on the purchase and sale of shares or mergers between companies.

Another source, now it's Forbes Mexico, in its issue of June 2014, presented the ranking of the 1,000 global companies. Banking and oil institutions lead the top ten of the list: finance and oil are the cornerstones of the global economy.

Within financial institutions the G8 group dominate the list; Australia achievement sneak in at No. 15, but what matters is that for the first time, China ranks number one ranking of the 1,000 global (and financial) companies measured in terms of sales and market value. While US companies have let slip that position, still retain hegemony in terms of volume of business.

Graphic 3. The 15 largest banks of the world

2014

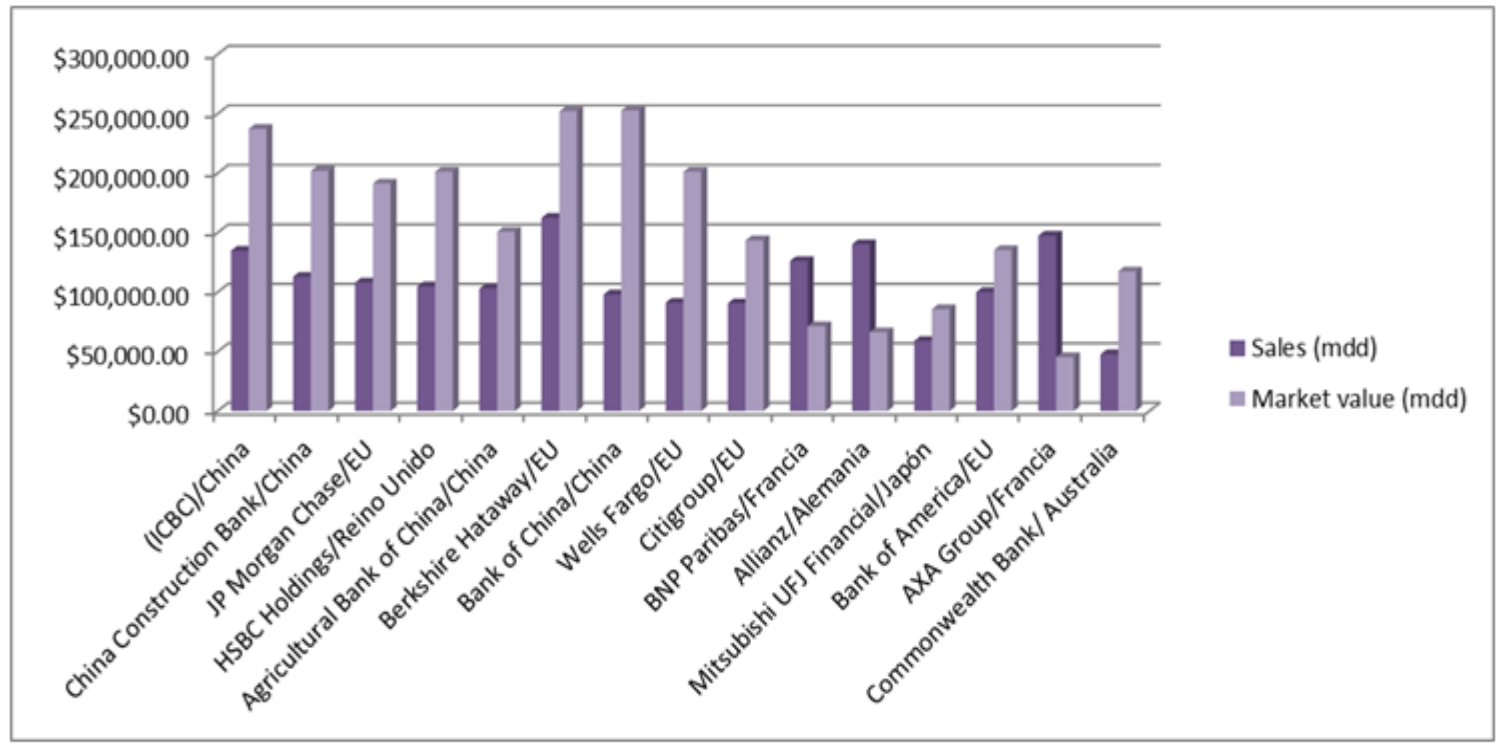

Source: Developing own. 
The benefits of TFC which tend to offer products and services with global uniformity characteristics can expand regionally, especially if the members governments in the region manage market policies favorable to the social, cultural and political harmonization (European Union) or economic integration (Nafta and Asia). [15]. In the case of Mexico is observed:

[...] Of the 7 biggest banks, 5 are subsidiaries abroad, so that the decisions of financing the Mexican private sector are taken by intermediaries with international business strategies, where each country is nothing but a sheet portfolios investment. [24].

In the specific case of Mexico, in 2013 the control by foreign bank, the three largest and integrate to financial groups is the next:

a) Foreign banks accounted for $82 \%$ of assets and $94 \%$ of the derivatives market. [5] Even the role of small foreign banks operating in Mexico is not marginal: although concentrated 4\% share in total assets and control the not inconsiderable figure of $33 \%$ in the derivatives market.

b) In this vein, Mexico's financial system is good to being great and being abroad, the three largest banks that meet these characteristics hold more than $52 \%$ of assets and account for $61 \%$ of profits. The other banks, 38 Mexican and foreign companies, has $48 \%$ of assets and only $39 \%$ of profits. [12:64]

c) Today the Mexican banking oligopoly is controlled by five financial groups, of which 4 belong to foreign capital. In 2012 the 5 biggest banks controlled $76.6 \%$ of total bank assets. [17]

\section{Credit and Transnational Financial Companies}

The credit is the essential link between the productive sphere and financial. Their role is crucial to define the relationship between the growth of the productive apparatus and the essential role of the financial system in development.

Indeed, one of the key aspects that explain and define the relationships between productive and financial sphere is the financing and the role here of TFC is crucial. With financial reforms spatial sphere of influence of monetary measures stopped working and moved to the international space. This gives a huge part of uncertainty and risk to production and financial cycles because they depend and no national space but world where there are no institutions, nor has the tools to gain a true regulation conducive to economic development.

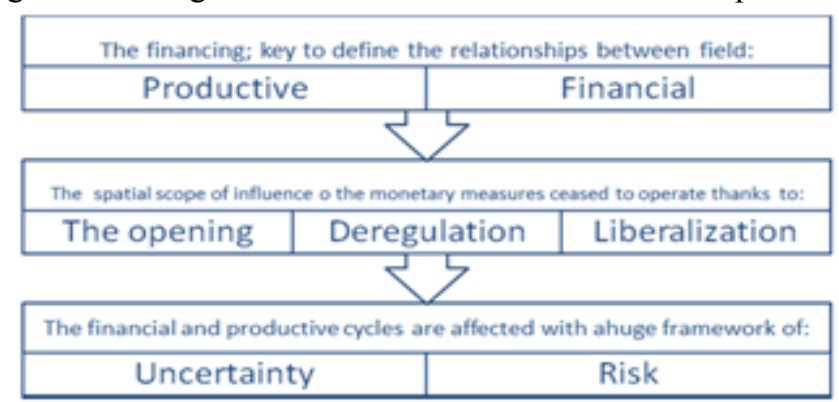

Source: Developing Own.

Figure 6. Productive and Financial Space

If we measure the microeconomic and macroeconomic efficiency of the banking system by the level of earnings and changes in ratio credit / GDP respectively, the data indicates that banks increased their microeconomic efficiency; however, if we consider the distribution and behavior of the loan portfolio, macroeconomic efficiency dropped because bank financing and production activities showed a steady decline. Note that this behavior of private banks by foreign firms also recorded in other developing economies. [17]

Microeconomic Vs Macroeconomic

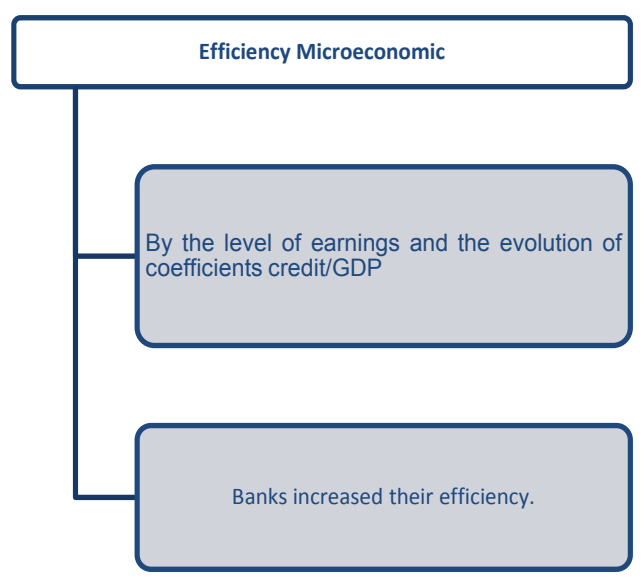

Source : Developing own

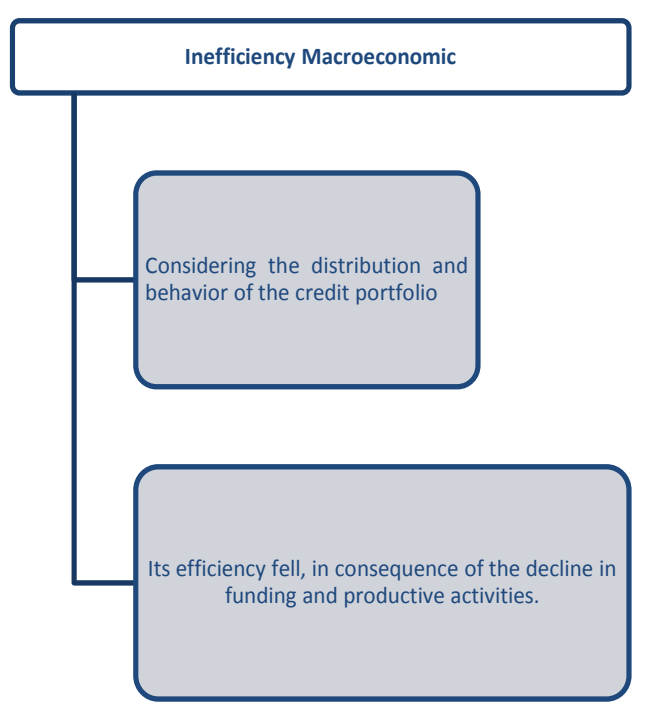

Figure 7. Efficient/Inefficiency 
Foreign banks expressed a contradictory dynamic: on the one hand, provides financing to foreign companies and large national companies - with the backing of the government of the country as a lender of last resort to save fraud or hidden ineffectiveness. [18] On the other hand, contracted lending to small and medium sized enterprises (SMEs); furthermore, after the crises of 1994-1995 and 2007 -2008, the (domestic and foreign) banking system is strongly capitalized, with high profitability ratios, satisfactory balances delinquency and risk coverage and liquidity indicators of the highest the planet, while its essential role in channeling resources to productive apparatus is greatly restricted.

\begin{tabular}{|l|l|l|}
\hline \multicolumn{2}{|l|}{$\begin{array}{l}\text { The banking system is heavily } \\
\text { capitalized with: }\end{array}$} & $\begin{array}{l}\text { Liquidity } \\
\text { indicators } \\
\text { of the } \\
\text { highest on } \\
\text { the planet. }\end{array}$ \\
\hline $\begin{array}{l}\text { Profitability } \\
\text { ratios high }\end{array}$ & $\begin{array}{l}\text { Satisfactory } \\
\text { balances of } \\
\text { delinquency }\end{array}$ & $\begin{array}{l}\text { Coverage } \\
\text { risks }\end{array}$ \\
\hline \hline
\end{tabular}

Source: Developing Own.

Figure 8. After the crisis of $1994-1995 \ldots$

The operations carried out by the TFC allow them to realize significant profits and profitability by rolling together and consolidated operations and actions performed: the margins obtained between deposit and lending rates (in real terms); dividends received by the possession of government bonds (eg CETES..); derivative transactions (hedges); indirect loans between parent and subsidiary; nonbank financial activities (insurance, trusts, exchange, leasing, etc.) and other non-financial activities such as the purchase or acquisition of property or its link with productive or commercial activities. All these actions are more profitable as a whole and have ended up getting the credit. [18:86]

In the case of Mexico, Guillermo Ortiz [19], former Secretary of Finance and Public Credit, and former president of Banorte, shook public opinion by stating:

"Between 2003 and 2011 the dividends paid by foreign-owned banks were 20 billion dollars, a dividend of three quarters of annual profits. If instead they had made a payment of one fifth of the dividend on average, as local banks would have distributed more capital in Mexico ". [19]

Two months later, the same former official Ortiz made another important statement:

"Obviously, the decision to pay dividends (part of the proceeds here) takes it in the womb, not here in the subsidiary. The payment system is a strategic space and to the extent that the authority does not exercise control over it, I think regulation is insufficient. The payment system is the nervous system, is the canal to irrigate the entire economy. Then, as in all major countries, must be controlled by nationals. [20]

Only companies rated AAA have agreed to the options of internal and external financing. [17:76]

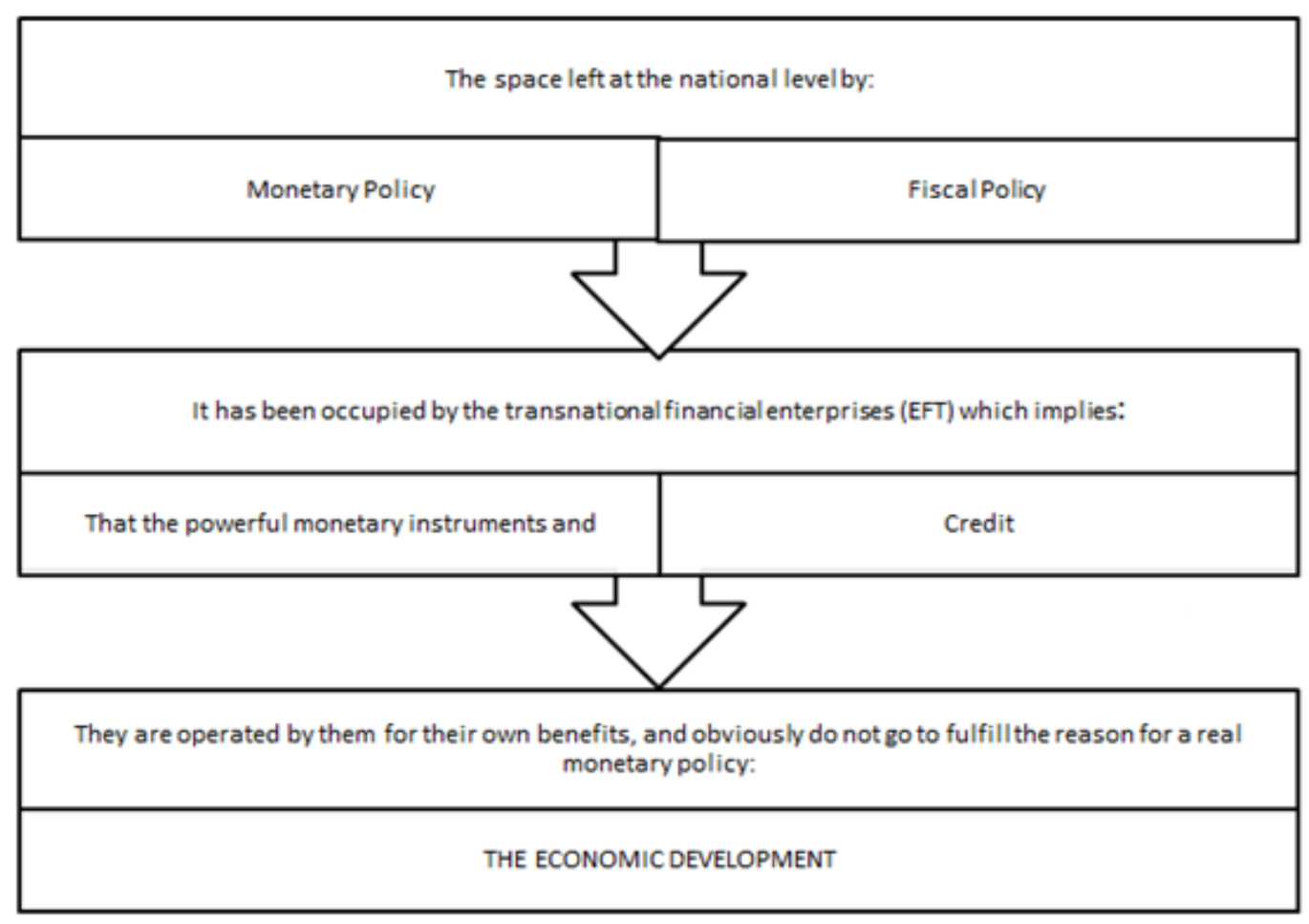

Source: Developing Own.

Figure 9. What we are proposing here 


\section{What to Do?}

If there is the political will to change the current financial scenario, you can perform a particular package:

- Apply a tax on each financial transaction.

- Require banks and insurers that $30 \%$ of its reserves the channeled to productive projects.

- Perform rigorous studies aimed at identifying the characteristics of the financial cycle (BIP) and its role in the economic cycle.

- Regulate internally the role of transnational financial firms without impeding the functioning of the financial cycle credit-investment-reinvestment.

- Raise deposit rates on deposits to combat oligopsony.

- Issue and implementation of a clear, common standards and controlling interest rates, capital flows, the bank ownership and participation in the various markets for financial products (credit, interest rates, deposit insurance foreign currency, etc...) including transactions in the capital markets.

Regulatory authorities and supervisory agencies should take into account all operations and activities of transnational banks. As noted by ECLAC [18] should consider the margins obtained between passive and active rates (in real terms); dividends received by the possession of government bonds (eg CETES), and enormously profitable operations in derivatives (hedges), indirect loans between parent and subsidiary; nonbank financial activities (insurance, trusts, exchange, leasing, etc.) and other non-financial activities by banks as the acquisition of property or its link with productive and commercial activities. All these activities together have ended up getting the credit. [18:86]

One of the central problems facing the countries where transnational banks operate is the diversity of regulations between countries and within the territories where they operate which greatly hinders its own regulation. As has been argued ECLAC [18:87], an important action to counteract this effect is the emission of a clear, common standards and controlling interest rates, capital flows, ownership of banks and participation in different markets of financial products (credit, interest rates, insurance of deposits in foreign currency, etc.) including transactions in the capital markets. [18]

The authorities should consider that transnational banks may have very different motivations to open agencies in a country. The motivations may be the development of bilateral trade, the granting of loans from the parent company, the attention of transnational companies or interest to bank and have direct exposure to the local market. Different motivations have different effects on banks and the market as a whole. That should be considered in the integration of a comprehensive and deep regulation. [18]

\section{Acknowledgements}

Thanks to my student Mariana Perez for helping integration tables, graphs and figures; Professor Romero Lara also for their willingness to translate this text.

\section{REFERENCES}

[1] Beck T, Demirgüc-Kunt A and Maksimovic V. Bank competition, financial obstacles and access to credit, Paper present at Conference on Bank Concentration and Competition, World Bank, April 3-4, 2003, Washington, D. C., USA.

[2] Goldberg L, Dages B G and Kinney D. When is U. S. Lending to emerging markets volatile, Federal Reserve Bank of New York, March, 2001.

[3] Peek J \& Rosengren and Rosengren E. The international transmission of financial shocks: the case of Japan. The American Economic Review, 1997, Vol. 90-1, pp. 30-45.

[4] Peek J and Rosengren E. Collateral Damage: Effects of the Japanese Bank Crisis on Real Activity in the United States. The American Economic Review, 2000, Vol. 87-4, pp. 495-505.

[5] Cardenas J, Graf J and O’Dogherty P. Foreign Banks entry in emerging Market economies: a host country perspective. The paper was prepared for the CGFS Working Group on FDI in the financial sector. Members of the Working Group contributed with useful comments. The authors work at the Financial System Analysis Division of Banco de México, 2004.

[6] Claessens S, Demirgüc-Kunt A and Huizinga H. How Does Foreign Presence Affect Domestic Banking Markets? Journal of Banking and Finance 25, 2001, pp. 891-911.

[7] Ugarteche O. Arquitectura financiera internacional: una genealogía de 1850 - 2008, 2014 Ed. IIE, UNAM.

[8] Lichtensztejn S. Internacionalización financiera en países emergentes: las experiencias monetarias de México y Uruguay, en Revista Ola Financiera, enero - abril 2015, No. 20 .

[9] Calva, JL. Sistema financiero para el Desarrollo. La Reforma de Peña Nieto y opciones para 2013-2020 en análisis estratégico para el desarrollo, 2013, volumen 6, editorial Juan Pablos Editor, UNAM, et. al primera edición.

[10] Zicolillo, J. La Era de las Corporaciones, Conjeturas, Ed. Lectorum, México 2014.

[11] Harvey, D. Breve historia del neoliberalismo, Ed. Akal No. 49, 1ª . Reimpresión, 2005.

[12] Gómez G y Patlán D. Regulación de la banca comercial en México: de la crisis de 1995 a la propuesta de reforma 2013-2018" En Calva, José Luís, Sistema financiero para el Desarrollo. La Reforma de Peña Nieto y opciones para 2013-2020 en análisis estratégico para el desarrollo, 2013, volumen 6, editorial Juan Pablos Editor, UNAM, et. al, primera edición.

[13] Reyes, J. Sector asegurador en México. Reestructuración, grupos financieros y crisis, 1980-2005, 2009 Ed. Instituto de 
Investigaciones Económicas, 2009, México.

[14] Garrido J. Desarrollo económico y procesos de financiamiento en México. Transformaciones contemporáneas y dilemas actuales. 2005, Ed. Siglo XXI y UAM, México.

[15] Rugman, A. Las multinacionales regionales, 2007, Editorial Akal, Madrid.

[16] Vitali S, Glattfer J y Battiston S. La Red de Control Corporativo Global en Revista Cientifica PlosOne.org., 2011

[17] Ortíz, L A. Extranjerización y estructura oligopólica de la banca comercial en México, en Calva, José Luís (2013) Sistema financiero para el Desarrollo. La Reforma de Peña Nieto y opciones para 2013-2020 en análisis estratégico para el desarrollo, 2013, volumen 6, editorial Juan Pablos Editor, UNAM, et. al, primera edición.

[18] ECLAC. La apertura financiera en Chile y el comportamiento de los bancos transnacionales, Estudios e Informes de la CEPAL, 1990 No. 78.

[19] Ortiz, G. Los mercados emergentes deben guiar la reforma bancaria, en Periódico La Jornada, México, marzo 62012.

[20] Ortiz, G. Periódico La Jornada, 14 de mayo 2012, México.

[21] Berger A, Kaplen L and Udell G. The ability of Banks to lend to informationally opaque small business Journal of Banking and Finance, 25, 2127-2167, 2001 U.S.A.

[22] Calderón G. Revista Gestión y Estrategia, julio - diciembre 1995, No. 8 UAM Azcapotzalco, México.

[23] Cárdenas, JA. Foreign banks entry and access to credit: does firm size matters? Mimeo. 2013, Banco de México.
[24] Centro de Estudios de las Finanzas Públicas (CEFP). Comentarios al Informe Estadístico sobre el Comportamiento de la Inversión Extranjera Directa en México (enero septiembre 2014), Cámara de Diputados, México.

[25] Clark G, Cull R and Martínez Peria M S. Does Foreign Bank penetration reduces access to credit in developing countries? Evidence from asking borrowers, 2002, World Bank. USA.

[26] Gasca J. Espacios Transnacionales. Interacción, integración y fragmentación en la frontera México - Estados Unidos, 2002 Ed. Miguel Ángel Porrúa y UNAM.

[27] Peek J \& Rosengren and Rosengren, E. Bank consolidation and small business lending: It is not just bank size that matters, Journal of Banking and Finance, 1998, 22, pp. 799-819.

[28] Reyes, J. Crisis soberana y políticas de ajuste en la zona euro e implicaciones en países emergentes, en Revista Ola Financiera 2012, No. 13, Instituto de Investigaciones Económicas, UNAM.

[29] Strahan, P and Weston J. Small Business Lending and the Changing Structure of the Banking Industry. Journal of Banking and Finance 1998, Vol. 22, pp. 821-845.

[30] UNCTAD. World Investment Report 2014: Investing in the SDGs: An Action Plan, junio 24, 2014, 265, pp. Disponible en Internet

http://unctad.org/en/PublicationsLibrary/wir2014_en.pdf.

[31] http://catarina.udlap.mx/u_dl_a/tales/documentos/lri/poo_d_ ai/capitulo1.pdf El papel de las empresas transnacionales en el mundo globalizado

[32] catarina.udlap.mx/u_dl_a/tales/documentos/lri/acosta.../capit ulo2.pdf Capítulo $\overline{2}$. Sobre la globalización, las empresas transnacionales y el Estado. 